\title{
THE EFFECT OF ADHERENCE TO ANTIRETROVIRAL THERAPY ON SURVIVAL IN PEOPLE LIVING WITH HIV/ AIDS: A NEW EVIDENCE FROM WAMENA, PAPUA
}

\author{
Tena Kogoya1), Argyo Demartoto²), Bhisma Murti1) \\ 1)Masters Program in Public Health, Universitas Sebelas Maret \\ ${ }^{2)}$ Faculty of Social and Political Sciences, Universitas Sebelas Maret
}

\begin{abstract}
Background: Life expectancy and healthcare for people living with HIV (PLWHAs) have improved substantially in the last two decades since effective antiretroviral therapy has been available, and still continue to improve. However, a fewstudies have reported that some PLWHAs did not adhere to take anti retroviral therapy (ART), which might have lessen the effectiveness of ART. Limited studies have reported about the effect of non-adherence on patient survival in Indonesia. The aim of this study was to estimate the effect of adherence to ART on PLWHA survival in Wamena, Papua, after controlling for nutritional status and age.

Subjects and Method: This was a retrospective cohort study conducted in Wamena Hospital, Papua from December 2017 to February 2018. A cohort of 304 PLWHA was selected for this study from the medical record at Wamena Hospital. The dependent variable was survival. The independent variables were adherence to ART, nutritional status, and age. The data were collected from medical record and questionnaire. The data were analyzed by Cox regression model.

Results: The risk of dying of PLWHA if adherent to take the ART was much lower than not adherent to take the ART $(\mathrm{HR}=0.04 ; 95 \% \mathrm{CI}=0.01$ to $0.29 ; \mathrm{p}=$ 0.001). The risk of dying of PLWHA with poor nutritional status was much higher than good nutritional status $(\mathrm{HR}=15.06 ; 95 \% \mathrm{CI}=8.14$ to $27.88 ; \mathrm{p}<0.001)$. The risk of dying of PLWHA aged $\geq 35$ years was slightly higher than $<35$ years $(\mathrm{HR}=$ $1.45 ; 95 \% \mathrm{CI}=0.98$ to $2.13 ; \mathrm{p}=0.062$ ).

Conclusion: The risk of dying of PLWHA decreases if adherent to take the ART, but increases with poor nutritional status and age $\geq 35$ years.
\end{abstract}

Keywords: survival, adherence to treatment, people living with HIV/ AIDS.

\section{Correspondence:}

Tena Kogoya. Masters Program in Public Health, Universitas Sebelas Maret.

Mid-International Conference on Public Health, Best Western Premier Hotel, Solo, Indonesia, 18-19 April 2018 | 255 https://doi.org/10.26911/mid.icph.2018.05.17 